\title{
ZASADA OSTROŻNOŚCI A KLASYCZNE REGUŁY DECYZYJNE
}

\begin{abstract}
Precautionary Principle vs Formal Decision: Making Criteria

Precautionary principle (PP) is commonly understood as a criterion that should be used in decision-making under risk and/or uncertainty. Yet, long before the approval of PP in the literature a set of concrete, formal criterions existed in the field of decision theory. Therefore the main goal of this paper is to compare these classical decision - rules with PP. This very comparison will bring us to answer the question: if PP may be reduced to any of the classical criterions? It will tur out that such a reduction cannot be done. Therefore PP has got its own specificity.
\end{abstract}

Keywords: precautionary principle, uncertainty, scientific uncertainty, decision theory, heuristics

\section{Streszczenie}

Zasada ostrożności (ZO) traktowana jest w literaturze przedmiotu jako reguła decyzyjna, która powinna być stosowana w sytuacjach charakteryzujących się niepewnością. Jednakże w ramach teorii decyzji już znacznie wcześniej wypracowano algorytmy postępowania w warunkach niepewności. Celem niniejszego artykułu jest porównanie klasycznych reguł decyzyjnych z zasada ostrożności i odpowiedź na pytanie: czy zasadę ostrożności można zredukować do którejś z klasycznych reguł. Okazuje się, że taka redukcja nie jest możliwa.

Słowa kluczowe: zasada ostrożności, niepewność, naukowa niepewność, teoria decyzji, heurystyki decyzyjne

JEL: D01, D81, G18, H12, I18

\section{Wstęp}

O ile ostrożność jest powszechnie aprobowanym i często rekomendowanym rodzajem zachowania, o tyle zasada ostrożności jest koncepcją problematyczną 
i kontrowersyjną. Na poziomie intuicyjnym dochodzi wielokrotnie do ich utożsamienia, a przecież są one zupełnie niezależnymi bytami.

Intuicja nie jest tylko predyspozycją osób nieuprawiających nauki. Przeciwnie. Bardzo często daje ona o sobie znać właśnie badaczom. Przejawem takiej intuicji jest przypuszczalne wrażenie, jakie zasada ostrożności wzbudza wśród uczonych zajmujących się problematyką teorii decyzji. Otóż w ramach tej dziedziny studiów, po uprzednim zapoznaniu się z definicją zasady ostrożności i z przykładami jej praktycznego zastosowania, może powstać wrażenie, że zasada ta jest jedną z wielu reguł decyzyjnych, jakie zna współczesna teoria decyzji. Co więcej, zasada ostrożności wydaje się imitować już istniejące formalne kryteria decyzyjne, które - notabene - określane są mianem ostrożnościowych. W szczególności chodzi tutaj o kryterium maximinu oraz kryterium Savage'a.

Celem niniejszego artykułu jest refleksja nad tym, czy o zasadzie ostrożności można orzekać jako o jednym $\mathrm{z}$ formalnych (to jest rozważanych $\mathrm{w}$ ramach teorii decyzji) kryteriów podejmowania decyzji, i czy możliwe jest zredukowanie $z a$ sady ostrożności do którejś z istniejących reguł.

Artykuł posiada następującą strukturę: w pierwszej części zostaje wyjaśniona geneza i znaczenie zasady ostrożności, a także omówione zostają szczególne warunki, jakie muszą zostać spełnione, aby owa koncepcja miała zastosowanie. Mianowicie chodzi o warunki niepewności oraz groźbę nieakceptowalnej katastrofy.

W kolejnej części zostają omówione najpopularniejsze, formalne kryteria podejmowania decyzji w warunkach niepewności, a następnie sprawdzone zostaje ich praktyczne zastosowanie na przykładzie rzeczywistej sytuacji decyzyjnej (problem otwarcia granic Unii Europejskiej (UE) na żywność genetycznie modyfikowaną), do rozstrzygnięcia której powoływano się na zasadę ostrożności. Na podstawie analizy rekomendacji poszczególnych kryteriów oraz samej zasady ostrożności zostaną wyciągnięte wnioski końcowe.

\section{Zasada ostrożności — historia, znaczenie, próba definicji}

Zasada ostrożności (dalej: ZO) jest wyrazem zdroworozsądkowego dążenia do ochrony fundamentalnych dóbr i wartości, których utrata jest nieakceptowana [Malinowski, 2018]. Początki ZO wiążą się z terminem Vorsorgeprinzip, który po raz pierwszy został zastosowany w ustawodawstwie niemieckim w 1974 roku na potrzeby tak zwanej ustawy o czystym powietrzu. Na uwage zasługuje to, że polski termin ostrożność niezupełnie pokrywa się z niemieckim Vorsorge. Ostrożność w języku polskim kojarzy się przede wszystkim z zaprzestaniem jakiejś aktywności i dotyczy głównie czasu teraźniejszego. Tymczasem Vorsorge odnosi się przede wszystkim do przyszłości i stanowi wezwanie do podjęcia działania.

O ZO najczęściej mówi się w kontekście tych wartości i dóbr, których utrata jest nieodwracalna. Nie dziwi zatem, że w ostatnich dekadach obserwuje się rozszerzanie się kontekstu posługiwania się tym terminem. Wszakże ZO pojawia się 
najpierw w dyskusjach na tematy związane z szeroko rozumianą ochroną środowiska naturalnego [Raffensperger, 1999], następnie przenika do dyskursu związanego ze zdrowiem publicznym [Resnik, 2004], by potem stać się elementem debaty dotyczącej dziedzictwa kulturowego, życia politycznego oraz gospodarki. W tym kontekście coraz częściej mówi się o tak zwanej uniwersalnej zasadzie ostrożności, która powinna stanowić milczącą bądź prawnie usankcjonowaną podstawę polityki związanej ze środowiskiem naturalnym, kulturą oraz gospodarką [Akins i in., 2019].

W 1984 roku ZO została przywołana podczas międzynarodowej konferencji poświęconej ochronie Morza Północnego. W 1985 roku powoływano się na nią podczas konwencji wiedeńskiej w sprawie ochrony warstwy ozonowej, w czasie której wskazywano na potrzebę stosowania „środków ostrożności”. Od tego czasu ZO stała się elementem prawa międzynarodowego przywoływanym bezpośrednio przez liczne akty normatywne. Wśród nich należy wymienić:

- Drugą deklarację ministerialną dla Morza Północnego (1987);

- Trzecią deklarację ministerialną dla Morza Północnego (1990);

- Deklarację z Rio w sprawie środowiska i rozwoju (1992);

- Traktat o Unii Europejskiej (1992),

- Komunikat Komisji Europejskiej dotyczący zasady ostrożności (2000);

- Konstytucję Francji (2005).

Ponadto sformułowania w swej istocie bardzo bliskie ZO są obecne w ustawach zasadniczych takich krajów jak: Szwecja, Belgia, Holandia, Hiszpania, Wielka Brytania czy Australia. Na uwagę zasługuje to, że niezwykle trudnym zadaniem, wymagającym osobnych badań, jest ustalenie tego, czym z punktu widzenia teorii prawa jest ZO. O ile bowiem sama obecność w aktach normatywnych powinna stanowić rację wystarczającą do uznania $\mathrm{ZO}$ za swego rodzaju powszechną zasade prawa, o tyle definicyjna nieostrość oraz trudność w odróżnieniu ZO od zwykłej ostrożności powodują, że jej status jest trudny do określenia.

Niestety, nie jest możliwe przy toczenie jednej definicji ZO, która byłaby akceptowalna dla wszystkich badaczy tego zagadnienia. Definicja ta podlega stopniowym modyfikacjom. Zmiany te wymuszane są po pierwsze przez praktykę tworzenia aktów prawnych, w których ZO regularnie się pojawia, a po drugie przez kolejne fale teoretycznej refleksji nad istotą i znaczeniem ZO.

Trudność w sformułowaniu jasnej definicji ZO najlepiej zobrazować, odwołując się do jej dwóch skrajnych, wręcz karykaturalnych sformułowań. Za Gardinerem [2006] możemy przedstawić ZO w formie ultrakonserwatywnej i nadać jej następującą treść:

Należy zakazać wszelkich działań, które można podejrzewać z jakiegokolwiek powodu o to, że mogą wyrządzić jakąkolwiek szkodę.

Drugą skrajnością jest natomiast ultraminimalna definicja:

Należy obawiać się działań, które z prawdopodobieństwem 99,9\% doprowadzą do końca świata. 
Obydwie definicje uniemożliwiają praktyczne stosowanie ZO. Pierwsza ze względu na to, że paraliżowałaby większość działań, druga zaś dlatego, iż warunki jej stosowalności są niemożliwe do osiągnięcia. Refleksja nad tymi dwoma sformułowaniami jest jednak znamienna - niczym w krzywym zwierciadle - można w nich dostrzec niebezpieczeństwa związane z próbą stosowania ZO jako reguły decyzyjnej. Większość krytyków ZO [Sunstein 2003, 2005; Scruton, 2012], chcąc podważyć jej rację bytu, usiłuje zredukować brzmienie ZO właśnie do wersji ultrakonserwatywnej. Forma ultrakonserwatywna wykorzystywana jest zazwyczaj jako swoisty „straszak”, za pomocą którego argumentuje się, że upowszechnienie ZO może oznaczać koniec działalności innowacyjnej. Z kolei zwolennicy ZO - próbując ją przedstawić w korzystnym świetle - formułują definicje bliższe wersji ultraminimalnej.

Powyższe sformułowania nie nadają się do stosowania w podejmowaniu decyzji, ale mają pewną wartość informacyjną, wyznaczają bowiem dwa bieguny, między którymi musi znaleźć się sensowna definicja. ZO określana bywa czasami mianem „teoretycznie ustrukturyzowanej paniki”, a z tego wynika, że podstawową funkcją definicji ZO jest maksymalnie precyzyjne wskazanie warunków, w jakich owa panika może wybuchać.

W literaturze przedmiotu najczęściej pojawiają się następujące definicje:

- „Wówczas, gdy dana aktywność zagraża życiu ludzkiemu lub środowisku naturalnemu, należy stosować środki ostrożności i to, nawet jeśli pewne związki przyczynowo-skutkowe nie zostały w pełni stwierdzone naukowo. W tym kontekście ciężar dowodu spoczywa na stronie proponującej dane działanie" [Wingspread, 1998].

- „Tam, gdzie występują zagrożenia poważnymi lub nieodwracalnymi zmianami, brak całkowitej naukowej pewności nie może być powodem opóźniania efektywnych działań nakierowanych na zapobieganie degradacji środowiska" (zob. zasada 15 Deklaracji z Rio w sprawie środowiska i rozwoju).

- „Decydent powinien stosować adekwatne środki ostrożności w celu zapobiegania lub mitygacji (poważnych i prawdopodobnych) zagrożeń [Resnik, 2004].

- „ZO wskazuje, że wówczas, kiedy ryzyko danej działalności jest niejasne lub nieznane, to należy założyć najgorszy scenariusz i zaniechać tej aktywności" [US Chamber of Commerce, 2004].

Należy też zauważyć, że część autorów formułuje rozwinięte definicje ZO i konstruuje całe „bloki pojęciowe” [Vlek, 2009; Randall, 2011], których zadaniem jest zdefiniowanie oraz operacjonalizacja ZO.

Zarysowana mnogość sformułowań tylko uwidacznia, że zdefiniowanie ZO nie jest sprawą prostą. Od kilku dekad toczy się na ten temat debata i najprawdopodobniej nie zakończy się ona spektakularnym konsensusem z tego względu, że część teoretyków postrzega ZO przede wszystkim jako przepis prawny, a więc jako normę legalistyczną, która musi być na tyle precyzyjna, ażeby mogła być egzekwowana chociażby przez sądy powszechne. Część badaczy usiłuje nadać ZO charakter algorytmu matematycznego, którego poprawne funkcjonowanie uzależnione jest od syntaktycznej i semantycznej poprawności tworzącej go formuły. Z kolei dla 
innych (w tym także dla autora tego tekstu) naturę $\mathrm{ZO}$ znacznie lepiej przybliżają takie określenia jak ,,heurystyka”, „pryncypium” czy „dyrektywa praktyczna”.

Celem niniejszego artykułu nie jest zajęcie stanowiska w sprawie definicji ZO. Dotychczasowe rozważania miały na celu jedynie zasygnalizowanie trudności związanych z definiowaniem ZO z jednej strony, a z drugiej - poziomu zaawansowania toczonej w tej kwestii debaty. $Z$ tych względów w niniejszym artykule będę posługiwał się następującą definicją ZO:

Jeżeli istnieją racjonalne podstawy do twierdzenia, że aktywność X powoduje nieakceptowalne społecznie zagrożenie, to aktywność $\mathrm{X}$ nie może być podejmowana w razie braku naukowej pewności odnośnie do jej bezpieczeństwa [Malinowski, $2018]^{1}$.

Wstępna analiza definicji pozwala stwierdzić, że ZO jest regułą decyzyjną, ponieważ $\mathrm{w}$ swej istocie jest przepisem na podjęcie decyzji w przypadku pewnego rodzaju sytuacji problemowej. Okazuje się jednak, że fundamentalną kwestią ZO jest sprecyzowanie okoliczności kształtujących sytuacje, w których ZO może być stosowana. Zagadnienie to zostanie rozwinięte w dalszej części artykułu. Na tym etapie zatrzymamy się na stwierdzeniu, że - w świetle przedstawionej definicji pewna sytuacja decyzyjna może być rozpatrywana pod kątem zastosowania ZO tylko wówczas, gdy występują jednocześnie dwa elementy:

- niepewność sensu largo i niepewność nauki sensu stricto,

- nieakceptowalne społecznie zagrożenie.

Po pierwsze należy wprowadzić wyraźne rozróżnienie między „ryzykiem” a „niepewnością”. Termin „ryzyko” odnosi się do sytuacji, w której zbiór wszystkich możliwych wyników jest określony, a prawdopodobieństwo wystąpienia każdego z nich jest znane decydentowi. Z kolei „niepewność” pojawia się wówczas, gdy decydent nie jest w stanie określić prawdopodobieństwa poszczególnych wyników. W konsekwencji ryzyko jest kategorią mierzalną, w odróżnieniu od niemierzalnej niepewności.

W niniejszym tekście, idąc za typologią sugerowaną przez Stirlinga i Gee [2002], termin „niepewność” używany jest w odniesieniu do trzech typów sytuacji:

A. Znany jest zbiór wszystkich możliwych wyników, ale nie jest znane prawdopodobieństwo każdego z nich.

B. Nie jest znany zbiór możliwych wyników i nie są znane ich prawdopodobieństwa.

C. Nie jest znany zbiór możliwych wyników, ale istnieją racjonalne, zdroworozsądkowe podstawy do orzekania o pewnych wynikach jako bardziej prawdopodobnych od innych.

1 W artykule nie została podana druga część definicji o następującej treści: „Jeżeli istnieją uzasadnione podstawy do twierdzenia, że aktywność X eliminuje/zmniejsza nieakceptowalne społecznie zagrożenie, to aktywność $\mathrm{X}$ powinna być podejmowana nawet $\mathrm{w}$ razie braku naukowej pewności odnośnie do jej bezpieczeństwa. Powodem takiego stanu rzeczy jest fakt, że na potrzeby niniejszego tekstu, pierwsza część definicji jest wystarczająca”. 
Z kolei termin „niepewność nauki” używany jest do określenia szczególnej kategorii niepewności. W kategoriach analizy zakresu terminologicznego uprawnione jest stwierdzenie, że zakres znaczeniowy terminu „niepewność” zawiera w sobie zakres znaczeniowy terminu „,niepewność nauki”.

„Naukowa niepewność" dotyczy faktu zmienności i ewolucji samych teorii naukowych, a więc fluktuacji rozumienia zjawisk zachodzących w świecie [Malinowski, 2019]. Decydent stojący w obliczu wyboru X powinien poprzedzić go (w miarę możliwości) ustaleniem stanu wiedzy na temat problematyki związanej z decyzjami typu X. Za niewymagające dowodu przyjmuję stwierdzenie, że „ustalić stan wiedzy na temat X” jest równoznaczne ze stwierdzeniem „ustalić, co na temat X mówi współczesna nauka". Jeżeli więc decydent podejmuje decyzję na podstawie aktualnego stanu wiedzy, a ów stan wiedzy w danej chwili jest niekompletny, gdyż podlega procesowi ciągłego doskonalenia, to oznacza, że podejmuje on ją de facto $\mathrm{w}$ warunkach niepewności. W świetle przedstawionej wcześniej typologii niepewności można stwierdzić, że ów decydent znajduje się w sytuacji, w której - w najlepszym razie - „nie jest znany zbiór możliwych wyników, ale istnieją racjonalne, zdroworozsądkowe podstawy do orzekania o pewnych wynikach jako bardziej prawdopodobnych od innych".

Naukowa niepewność oznacza więc niepełną wiedzę na dany temat. Z punktu widzenia teorii decyzji i zwykłego pragmatyzmu istotne jest, czy istnieje choćby niedoskonały sposób na określenie poziomu zaufania względem danego twierdzenia naukowego ${ }^{2}$. Próby wskazania takiego kryterium istnieją i są praktykowane między innymi w odniesieniu do problematyki zmian klimatycznych. Moss i Schneider [2000] wprowadzili klasyfikację, mającą na celu wskazanie poziomu pewności odnośnie do prawdziwości danego twierdzenia naukowego. Zważywszy na jakość oraz liczbę dowodów potwierdzających dane twierdzenie, badacze zaproponowali pięć przedziałów ufności:

- $95-100 \%$ - bardzo wysoki poziom wiarygodności,

- $67-95 \%$ - wysoki poziom wiarygodności,

- 33-67\% - średni poziom wiarygodności,

- 5-33\% - niski poziom wiarygodności,

- $0-5 \%$ - bardzo niski poziom wiarygodności.

Przedziały te powinny stanowić pomoc w doprecyzowaniu, jakiego rodzaju działanie zaleca $\mathrm{ZO}$ w konkretnych sytuacjach decyzyjnych.

Z kolei pod pojęciem „nieakceptowalnego społecznie zagrożenia” kryje się groźba zdarzenia o nieodwracalnych efektach, których za wszelką cenę pragnie uniknąć decydent - społeczność. Groźba ta jest możliwa, ale z reguły ustalenie prawdopodobieństwa jej wystąpienia jest niemożliwe. Ze względu na swój zakres i dotkliwość, ewentualną materializację tego rodzaju zagrożenia należy postrzegać w kategoriach „śmiertelnego ciosu”, a więc zjawiska, które potencjalnie może przerwać ciągłość czasową istnienia danego bytu: świata, kraju, narodu itp.

2 Mam na myśli twierdzenia naukowe syntetyczne (empiryczne) - w odróżnieniu od twierdzeń naukowych analitycznych, których prawdziwość można udowodnić formalnie. 
Reasumując, wykazane zostało, że ZO jest realnie istniejącą i funkcjonującą w przestrzeni prawnej regułą decyzyjną, której ambicje wykraczają daleko poza znalezienie sobie stałego miejsca $\mathrm{w}$ problematyce podejmowania decyzji. Aspiracje te natrafiają jednak na silny opór, gdyż za nieostrością definicyjną ZO kryją się liczne niebezpieczeństwa związane z możliwością nadużywania tejże.

\section{Kryteria podejmowania decyzji w warunkach niepewności}

Większość sformułowań ZO zawiera w sobie jakiś komponent łączący ZO z niepewnością. W konsekwencji niektórzy określają ZO mianem „paradygmatu”, którym należy się kierować w warunkach niepewności [Tickner, Geiser, 2004]. Takie stanowisko jest jednak problematyczne, ponieważ piśmiennictwo związane z teorią decyzji od wielu dekad już obfituje w rozważania dotyczące właśnie problemu podejmowania decyzji w warunkach niepewności. Co więcej, badania poświęcone temu zagadnieniu zwieńczone zostały sformułowaniem konkretnych kryteriów - reguł decyzyjnych. Każda z tych reguł ma określone właściwości, wady oraz zalety, a wybór którejś z nich jako podstawy działania w konkretnej sytuacji decyzyjnej jest zawsze w pewnej mierze arbitralny. $Z$ uwagi na zasadniczy cel niniejszego tekstu istotne jest omówienie tych podstawowych regul, wskazanie ich właściwości oraz przedstawienie możliwości ich praktycznego zastosowania.

Należy nadmienić, że najczęściej przytaczaną w ramach różnych dyscyplin regułą decyzyjną jest kryterium maksymalizacji przeciętnej wypłaty. Sugeruje ono decydentowi, który znajdując się w sytuacji wyboru, zna prawdopodobieństwo zajścia wszystkich możliwych stanów rzeczy, aby wybrał to rozwiązanie, które maksymalizuje przeciętną wartość wypłaty ze względu na dany rozkład prawdopodobieństwa. Jeżeli zatem liczby: $\mathrm{W}_{1}, \mathrm{~W}_{2}$ są wypłatami uzyskiwanymi $\mathrm{z}$ prawdopodobieństwem: $\mathrm{p}_{1}, \mathrm{p}_{2}$, to przeciętną wartością tych wypłat jest suma iloczynów tych liczb: $\left(\mathrm{W}_{1} \times \mathrm{p}_{1}\right)+\left(\mathrm{W}_{2} \times \mathrm{p}_{2}\right)$. Reguła decyzyjna zaleca maksymalizowanie tej wartości.

Reguła maksymalizacji przeciętnej wypłaty jest wygodnym narzędziem decyzyjnym, ale niestety jej zastosowanie ogranicza się wyłącznie do decyzji podejmowanych w warunkach ryzyka, a więc do sytuacji, w których decydent:

- zna wszystkie możliwe stany rzeczy,

- każdemu możliwemu stanowi rzeczy jest w stanie przypisać wartość prawdopodobieństwa.

Tymczasem przedmiotem zainteresowania niniejszego tekstu są warunki niepewności, a więc takie, w których co najmniej jedna z wyżej wymienionych okoliczności nie zachodzi.

Z tego względu reguły decyzyjne dotyczące warunków niepewności muszą posiadać tę cechę wspólną, że nie odwołują się bezpośrednio do rozkładu prawdopodobieństwa możliwych stanów rzeczy.

Teoria decyzji wypracowała wiele kryteriów tego typu. 
- Kryterium fatalistyczne - zaleca dokonanie takiego wariantu decyzyjnego, który przynosi najwyższą z maksymalnych wypłat.

- Kryterium maximinowe (Walda) - zaleca wybór takiego wariantu decyzyjnego, który zapewnia najwyższą z minimalnych wypłat.

- Kryterium Hurwicza - nakazuje ustalić wartość „współczynnika optymizmu" $(\alpha)$ z przedziału [0;1], a następnie dla każdego wariantu decyzyjnego obliczyć wartość:

$$
\alpha \times \text { maksymalna wypłata }+(1-\alpha) \times \text { minimalna wypłata }
$$

Następnie wybiera się decyzję z wyższą wartością wyrażenia.

- Kryterium Laplace'a - jest to w gruncie rzeczy zmodyfikowane kryterium maksymalizacji przeciętnej wypłaty. Zakłada ono, że jeśli decydentowi nie jest znany rozkład prawdopodobieństwa na zbiorze możliwych stanów rzeczy, to powinien przyjąć, że są one jednakowo prawdopodobne. Następnie zaleca wybór tego wariantu, w którym przeciętna wartość wypłaty jest najwyższa.

- Kryterium Savage'a - zastosowanie się do tej reguły odbywa się w trzech krokach:

Krok 1 - należy dokonać przekształcenia macierzy wypłat w „macierz strat”, w której każda wartość odpowiada różnicy między daną wartością z oryginalnej macierzy a najlepszym wynikiem, który można by uzyskać, gdyby znany był stan rzeczy, który ostatecznie się zmaterializuje.

Krok 2 - biorąc pod uwagę wszystkie możliwe wybory decydenta, należy wyznaczyć najwyższe wartości „strat” dla każdej decyzji.

Krok 3 - wybrać należy ten wariant, w którym najwyższa możliwa strata ma najniższą wartość.

\section{GMO, zasada ostrożności oraz klasyczne kryteria podejmowania decyzji}

Zapoznawszy się zarówno z ZO, jak i z klasycznymi kryteriami podejmowania decyzji w warunkach niepewności, spróbujmy teraz zasymulować sytuację problemową, ażeby porównać możliwości aplikacyjne ZO oraz pozostałych kryteriów. Takie praktyczne zastosowanie omawianych reguł powinno ujawnić specyfikę każdej z nich oraz przybliżyć nas do odpowiedzi na pytanie, czy ZO nie jest przypadkiem jedynie wariantem któregoś z klasycznych kryteriów.

Projektowana sytuacja problemowa musi posiadać określoną specyfikę po to, aby umożliwiła porównanie stosowalności ZO oraz innych reguł decyzyjnych. Wobec tego wydaje się, że najlepszym przykładem będzie powołanie się na realne zdarzenie i realne decyzje, których podjęcie wiązało się z wykorzystaniem ZO.

$Z$ tego względu odniesiemy się do kwestii zaleceń Unii Europejskiej dotyczących żywności genetycznie modyfikowanej (ang. genetically modified organism, 
GMO). Otóż w 2001 roku Unia Europejska wprowadziła przepisy, na mocy których dostawcy żywności GMO zmuszeni są do udowodnienia tego, że jest ona bezpieczna dla zdrowia. Istotą nowej legislacji było przesunięcie ciężaru dowodu - to nie regulator lub krytycy GMO mają udowadniać, że jest ono niebezpieczne, lecz podmiot wprowadzający taką żywność musi udowodnić, że jest ona bezpieczna. Należy podkreślić, że wspomniane regulacje prawne pośrednio odwołują się do ZO [Science for Environment Policy, 2017].

W związku z powyższym sytuacja decyzyjna przybiera następującą postać: decydent - Komisja Europejska stoi przed dylematem, czy (1) zabronić stosowania żywności GMO na terytorium Unii Europejskiej lub może (2) nie robić w tej sprawie nic (co jest równoznaczne z umożliwieniem wprowadzenia GMO na teren UE). Pierwsza opcja jest oczywiście przejawem daleko idącej ostrożności, zaś opcja druga jest wyrazem przekonania, że GMO jest produktem bezpiecznym. Decyzji Komisji Europejskiej odpowiadają dwa możliwe stany rzeczy. Może okazać się, że (1) żywność GMO jest zupełnie bezpieczna lub (2) żywność GMO jest zagrożeniem dla człowieka ${ }^{3}$. Dylemat ten obrazuje następująca macierz wypłat:

Tabela 1

Dylemat GMO

\begin{tabular}{|l|c|c|}
\hline & GMO jest bezpieczne & GMO jest zagrożeniem \\
\hline Zabronić GMO & $-100 \mathrm{mln}$ euro & $-100 \mathrm{mln}$ euro \\
\hline Nie robić nic & 0 & -100 mld euro \\
\hline
\end{tabular}

Źródło: opracowanie własne.

Macierz wypłat przedstawia hipotetyczne koszty związane z podjęciem danej decyzji ${ }^{4}$. Zakładamy, że wprowadzenie zakazu GMO będzie kosztowało Unię Europejską $100 \mathrm{mln}$ euro. $Z$ kolei niewprowadzanie regulacji anty-GMO nie będzie się wiązało z żadnym kosztem. Jeżeli czas pokaże, że GMO jest nieszkodliwe dla zdrowia człowieka, to uprzednie wprowadzenie zakazu GMO wiązać się będzie ze stratą $100 \mathrm{mln}$ euro. Jeżeli jednak okaże się, że GMO jest rzeczywistym zagrożeniem, wówczas strata związana $\mathrm{z}$ usuwaniem negatywnych konsekwencji GMO osiągnie wartość 100 mld euro (tabela 1).

Komentarza wymaga kwota 100 mld euro. Otóż istotą przykładu jest to, aby ta wypłata oznaczała materializację jakiegoś wielkiego zagrożenia. Zakładać należy

Zaznaczam, że przykład jest jedynie symulacją pewnego problemu decyzyjnego, która wprawdzie odnosi się do konkretnego wydarzenia, ale prawdopodobnie wcale nie jest jego wiernym odzwierciedleniem.

4 Przedstawione liczby nie mają żadnego związku z rzeczywistymi analizami. Mają na celu jedynie przybliżenie pewnego dylematu decyzyjnego. 
zatem, że wartość z tej pozycji ma charakter „ruiny” - ogromnej, nieodwracalnej straty. Jeżeli więc wartość 100 mld euro nie w pełni oddaje wartość tego rodzaju wydarzenia, to z punktu widzenia dalszych analiz, nic nie stoi na przeszkodzie, żeby zwiększyć ją do 1 bln euro lub 100 bln euro.

Powyższy przykład w dalszej części tekstu posłuży do testowania poszczególnych kryteriów decyzyjnych. Zanim to jednak nastąpi, należy zwrócić uwagę na pierwszą istotną kwestię, która odróżnia podejmowanie decyzji na podstawie ZO od podejmowania decyzji na podstawie innych, wymienionych reguł decyzyjnych. Chodzi mianowicie o samą możliwość skonstruowania macierzy wypłat.

Wniosek nr 1 - stosowanie ZO nie wymaga konstruowania macierzy wypłat.

W poprzednim paragrafie wykazane zostało, że ZO może być stosowana tylko wówczas, gdy decydent ma do czynienia z niepewnością. Zgodnie z wprowadzoną typologią Stirlinga i Gee [2002] warunki niepewności odnoszą się do trzech typów sytuacji. Decydent (A) zna wszystkie możliwe wyniki, lecz nie zna ich prawdopodobieństw, lub (B) nie zna zbioru możliwych wyników oraz ich prawdopodobieństw, lub (C) nie zna zbioru możliwych wyników, ale posiada racjonalne podstawy do orzekania o pewnych wynikach, jako bardziej prawdopodobnych od innych.

Otóż należy zauważyć, że tylko sytuacja A umożliwia zbudowanie macierzy wypłat. Jeżeli zaś decydent działa w obliczu ignorancji (B i C), wówczas nie są mu znane wszystkie możliwe stany natury, a przez to nie da się zbudować kompletnej macierzy wypłat. Powyższy wniosek można sformułować także w nieco inny sposób. Mianowicie do stosowania klasycznych reguł decyzyjnych konieczne jest skonstruowanie macierzy wypłat ${ }^{5}$.

Jeżeli pewne typy niepewności uniemożliwiają określenie liczby możliwych stanów rzeczy, to kłopotliwe staje się również przyporządkowanie poszczególnym wariantom wartości liczbowych. Klasyczne reguły decyzyjne wymagają, aby sytuacje problemowe przedstawiane były za pomocą wartości liczbowych, które są miarą preferencji decydenta. Oznacza to, że najsłabszą skalą pomiarową, jaką można się posługiwać, jest skala porządkowa ${ }^{6}$. Tymczasem warunki ignorancji oznaczają, że tego rodzaju skala nie może zostać zastosowana.

Wniosek nr 2 - stosowanie ZO nie wymaga przyporządkowania poszczególnym wynikom wartości liczbowej.

5 Z tych powodów można uznać wskazany przykład dotyczący GMO za zbyt uproszczony (bo nie dopuszcza większej liczby opcji decyzyjnych i możliwych stanów rzeczy) i taki jest w istocie. Niemniej jednak warunkiem koniecznym stosowania klasycznych kryteriów decyzyjnych jest dysponowanie macierzą wypłat.

6 Skala porządkowa oznacza, że poszczególne warianty mogą zostać uporządkowane w zależności od znaczenia (preferencji decydenta). 


\section{Aplikacja klasycznych kryteriów podejmowania decyzji}

Opisana w poprzednim paragrafie sytuacja problemowa umożliwia zbadanie tego, którą decyzję zalecają poszczególne kryteria decyzyjne.

\section{Kryterium fatalistyczne (maximaxowe)}

W podejściu tym ignorowane są prawdopodobieństwa wystąpienia poszczególnych stanów rzeczy, wobec tego zasadnicza analiza dotyczy jedynie wypłat końcowych. Kryterium zaleca wybór wariantu odznaczającego się maksymalną wypłatą. Innymi słowy, należy wybrać wariant charakteryzujący się minimalnym kosztem [Jablonowski, 2006].

Tabela 2

Kryterium fatalistyczne

\begin{tabular}{|l|c|c|c|}
\hline & $\begin{array}{c}\text { GMO jest } \\
\text { bezpieczne }\end{array}$ & GMO jest zagrożeniem & Minimalny koszt \\
\hline Zabronić GMO & -100 mln euro & -100 mln euro & $\mathbf{1 0 0}$ mln euro \\
\hline Nie robić nic & 0 & -100 mld euro & 0 \\
\hline
\end{tabular}

Źródło: opracowanie własne.

W rozpatrywanym przykładzie (tabela 2) minimalny koszt zabronienia GMO wynosi $100 \mathrm{mln}$ euro, natomiast minimalny koszt braku działań w tym zakresie jest równy zeru. Wobec tego kryterium zaleca podjęcie drugiej decyzji. Warto zauważyć, że ignorowanie prawdopodobieństwa wystąpienia zdarzenia o charakterze ruiny czyni kryterium fatalistyczne regułą bardzo optymistyczną. W zasadzie reguła ta nigdy nie będzie stała po stronie żadnych działań o charakterze ostrożnościowym, gdyż one zazwyczaj wiążą się z jakimś kosztem. Uprawnione jest zatem stwierdzenie, że kryterium jest „ślepe” na ryzyko.

\section{Kryterium maximinowe (Walda)}

O ile kryterium fatalistyczne określone zostało przymiotnikiem „optymistyczne”, o tyle kryterium maximinowe jest zdecydowanie ,pesymistyczne”. Ten algorytm decyzyjny również nie przewiduje żadnego przyporządkowania wartości prawdopodobieństwa poszczególnym stanom rzeczy. Zamiast tego, kryterium koncentruje się na unikaniu „najgorszego scenariusza”. Oznacza to, że należy wybrać ten wariant decyzyjny, w którym maksymalny koszt jest najniższy. 
Kryterium maximinowe (Walda)

\begin{tabular}{|l|c|c|c|}
\hline & GMO jest bezpieczne & GMO jest zagrożeniem & Maksymalny koszt \\
\hline Zabronić GMO & $-100 \mathrm{mln}$ euro & $-100 \mathrm{mln}$ euro & $\mathbf{1 0 0} \mathbf{m l n}$ euro \\
\hline Nie robić nic & 0 & $-100 \mathrm{mld}$ euro & $\mathbf{1 0 0}$ mld euro \\
\hline
\end{tabular}

Źródło: opracowanie własne.

W rozważanym przykładzie (tabela 3) najgorszym scenariuszem jest oczywiście sytuacja, w której nie zostały podjęte żadne środki ostrożności, a zarazem okazało się, że GMO jest zagrożeniem. Taka ewentualność wiąże się z rujnującym kosztem na poziomie 100 mld euro. Dlatego strategia maximinowa zaleca podjęcie decyzji, która nie wiąże się z takim ryzykiem, a więc zabronienia GMO. Warto zwrócić uwagę na zasadnicze wady tej reguły decyzyjnej. Przede wszystkim zupełne ignorowanie prawdopodobieństw oznacza, że jest ona podatna na wybuchy zupełnie nieracjonalnej paniki. Wystarczy tylko w taki sposób przedstawić sytuację decyzyjną, aby wiązała się z jakąś wielką stratą. Na przykład decydent postępujący zgodnie z kryterium stanie przed nie lada wyzwaniem, gdy uświadomi sobie, że tak spontaniczna decyzja jak wyjście $\mathrm{z}$ domu do pracy wiąże się z możliwością bycia trafionym przez meteoryt ${ }^{7}$, a w konsekwencji - z natychmiastową śmiercią. Chęć uniknięcia takiego scenariusza powoduje, że decydent musi wybrać opcję bezpieczną, niezależnie od tego, jak bardzo iluzoryczne i nieprawdopodobne jest zagrożenie.

Ponadto, ostrożność będąca fundamentalną motywacją kryterium maximinowego może być rujnująca dla decydenta. Gdyby nieco zmodyfikować nasz przykład w taki sposób, że decyzja ,zabronić GMO” wiązałaby się z kosztem na poziomie 99,99 mld euro, to - pomimo że koszt ten jest niemal równy stracie związanej $\mathrm{z}$ materializacją najgorszego scenariusza - kryterium nakaże podjęcie tej właśnie decyzji. Ponownie oznacza to, że iluzoryczność danego zagrożenia nie stanowi żadnego ograniczenia, nawet jeśli koszt ostrożności jest niemal tak samo rujnujący jak samo zagrożenie. Innymi słowy, kierowanie się kryterium maximinu prowadzi do „paradoksu ostrożności” [Jablonowski, 2005] polegającego na tym, że w celu zabezpieczenia się przed (nawet teoretyczną) stratą, decydent powinien być skłonny wydać niemal tyle, ile wynosi sama strata. $Z$ tych względów kryterium maximinowe ma niewielkie znaczenie praktyczne.

7 Zakładam, że przebywając w domu nie ma takiej możliwości. 


\section{Kryterium Savage'a}

Gdyby należało umieścić kryterium Savage'a na swego rodzaju skali optymizmu, której krańce wyznaczają z jednej strony kryterium fatalistyczne, a z drugiej - kryterium maximinowe, znalazłoby się ono bardzo blisko kryterium Walda. Jest tak dlatego, że kryterium Savage'a daje się zredukować do kryterium maximinowego, ale stosowanego względem zmodyfikowanej macierzy wypłat, którą określa się mianem „macierzy strat”. Psychologicznym podłożem warunkującym konieczność konstrukcji macierzy strat jest stan „zawodu”, którego miarą jest różnica między maksymalną wypłatą a wypłatą rzeczywistą, jaką można uzyskać, znając z góry stan rzeczy, który się zmaterializował. Innymi słowy, kryterium sugeruje, aby zminimalizować maksymalną stratę, jaką możemy odczuć, gdy określony stan rzeczy się zmaterializuje [Straffin, 2004]. W rozważanym przykładzie tabela strat wygląda następująco (tabela 4):

Tabela 4

Macierz strat

\begin{tabular}{|l|c|c|}
\hline & GMO jest bezpieczne & GMO jest zagrożeniem \\
\hline Zabronić GMO & $100 \mathrm{mln}$ & 0 \\
\hline Nie robić nic & 0 & $99,9 \mathrm{mld}$ \\
\hline
\end{tabular}

Źródło: opracowanie własne.

Kolejnym krokiem jest wyznaczenie najwyższych wartości strat dla każdej decyzji. Ten krok stanowi de facto aplikację reguły maximinu. Dla pierwszej decyzji najwyższa możliwa strata to $100 \mathrm{mln}$ euro, a dla drugiej - 99,9 mld euro. Ponieważ kryterium zaleca minimalizację najwyższej możliwej straty, dlatego ostatecznym rozstrzygnięciem jest wybór opcji „zabronić GMO”.

Podstawowe zastrzeżenia do kryterium Savage'a są podobne do obiekcji względem kryterium maximinu. Dodatkowa wada tego kryterium polega na wrażliwości na dodanie wiersza ${ }^{8}$. Jest to jednak słabość uwidaczniająca się w pewnych sytuacjach decyzyjnych rozważanych w ramach teorii gier i w naszym przykładzie, ze względu na jego arytmetyczną prostotę, nie jest możliwa do wskazania.

Ponadto należy zauważyć, że prostota rozważanego przykładu w połączeniu z tym, że wypłaty w nim zawarte przedstawione są już w formie straty/kosztu (w sensie psychologicznym istotą decyzji jest ograniczanie możliwej straty)

8 Zdaniem Straffina [2004] kryterium decyzyjne powinno być odporne na dodanie wiersza. Stanowi to jeden $\mathrm{z}$ teoriogrowych aksjomatów racjonalności decyzji. Dodanie wiersza to powiększenie zbioru dostępnych decyzji, przy czym jest on powiększony o decyzję identyczną z jedną z już istniejących. 
powodują, że transformowanie macierzy decyzyjnej w macierz strat tylko niepotrzebnie komplikuje sposób, w jaki decydent postrzega sytuację.

\section{Kryterium Hurwicza}

Jest to pierwsze $\mathrm{z}$ rozważanych kryteriów, które w pewnym sensie uzupełnia brak przypisania prawdopodobieństwa do poszczególnych stanów natury. Efekt ten zostaje uzyskany w wyniku wprowadzenia tak zwanego „współczynnika optymizmu" $(\alpha)$ z przedziału [0,1]. Wartość tego parametru zostaje utożsamiona z prawdopodobieństwem zmaterializowania się najbardziej optymistycznego scenariusza (maksymalnej wypłaty). Z kolei wyrażenie $(1-\alpha)$ staje się w ramach kryterium Hurwicza „współczynnikiem pesymizmu”. Następnie algorytm postępowania nakazuje, aby dla każdej decyzji obliczona została wartość:

$$
\alpha \times \text { maksymalna wypłata }+(1-\alpha) \times \text { minimalna wypłata }
$$

Powinna wybrana zostać decyzja posiadająca najwyższy wynik.

Należy zauważyć, że współczynnik optymizmu jest wartością subiektywną, chociaż może opierać się na nieintuicyjnych, racjonalnych podstawach. W rozważanym przykładzie (tabela 5), jeżeli założymy, że $\alpha=0,8$ to uzyskamy wynik -100 mln euro dla decyzji „,zabronić GMO” oraz -20 mld euro dla decyzji „nie robić nic". Wobec tego okazuje się, że nawet jeśli decydent jest umiarkowanym optymistą, to i tak kryterium Hurwicza nakazuje mu wybór opcji ostrożnościowej.

Tabela 5

Kryterium Hurwicza (dla $\alpha=0,8)$

\begin{tabular}{|l|c|c|c|}
\hline & $\begin{array}{c}\text { GMO jest } \\
\text { bezpieczne }\end{array}$ & GMO jest zagrożeniem & $\begin{array}{c}\alpha \times \max +(1-\alpha) \times \\
\times \text { min }\end{array}$ \\
\hline Zabronić GMO & -100 mln euro & -100 mln euro & $-100 \mathrm{mln}$ \\
\hline Nie robić nic & 0 & -100 mld euro & $-20 \mathrm{mld}$ \\
\hline
\end{tabular}

Źródło: opracowanie własne.

Warto zwrócić uwagę na pewne nieoczywiste właściwości tej reguły decyzyjnej. Otóż gdyby przyjąć, że $\alpha=1$, wówczas rezultat jest identyczny, jak w podejściu fatalistycznym. Gdy zaś $\alpha=0$, kryterium de facto redukuje się do reguły maximinowej. $Z$ tego wynika, że zasadniczą motywacją do stworzenia kryterium Hurwicza była chęć swego rodzaju zbilansowania pesymizmu podejścia ostrożnościowego i optymizmu podejścia fatalistycznego. 


\section{Kryterium Laplace'a}

W tej regule również pośrednio próbuje się przypisać wartość prawdopodobieństwa poszczególnym stanom rzeczy. W przeciwieństwie jednak do kryterium Hurwicza, odbywa się to w sposób arbitralny, niezależny od decydenta. Zakłada się, że decydent nie ma wystarczających, racjonalnych argumentów przemawiających za tym, że dany stan rzeczy jest bardziej prawdopodobny od innego. Prowadzi to do dyrektywy zwanej zasada racji niedostatecznej sugerującej, że wszystkie możliwe stany rzeczy należy traktować jako tak samo prawdopodobne. Kolejnym krokiem jest obliczenie oczekiwanej wartości wypłaty dla każdej decyzji, co w związku z tym, że każdy stan rzeczy jest tak samo prawdopodobny (wynosi 50\%) - sprowadza się do obliczenia średniej wartości wypłaty dla każdej decyzji.

W przypadku dylematu dotyczącego GMO średnia wypłata dla pierwszej decyzji wynosi $100 \mathrm{mln}$, a dla decyzji drugiej - $50 \mathrm{mld}$. Decyzja pierwsza odznacza się wyższą wartością oczekiwaną, w związku z tym kryterium sugeruje właśnie to działanie.

Podstawowym zastrzeżeniem wobec kryterium Laplace'a jest sprzeciw względem twierdzenia, że nie dysponujemy absolutnie żadnymi racjonalnymi argumentami pozwalającymi stwierdzić, że jakiś stan rzeczy jest bardziej prawdopodobny od innego. Nawet rozważając wspomniany wcześniej przykład obawy przed uderzeniem meteorytu możemy - na podstawie chociażby dowodów historycznych - orzec, że bycie trafionym przez meteoryt w drodze do pracy jest mniej prawdopodobne niż brak jakiejkolwiek styczności z meteorytem danego dnia. W tym kontekście warto zwrócić też uwagę, że kryterium Laplace'a jest wrażliwe na tak zwaną duplikację kolumny ${ }^{9}$ [Straffin, 2004]. Intuicja podpowiada, że zduplikowanie jakiejś kolumny w macierzy decyzyjnej nie powinno mieć wpływu na sugerowane przez dane kryterium rozwiązanie. W przypadku kryterium Laplace'a jest inaczej i w pewnych sytuacjach duplikacja kolumny prowadzi do zmiany zalecanej strategii.

Ponadto zarzuca się tej regule, że jest ,ślepa" na ryzyko. Wyobraźmy sobie, że decydent ma do wyboru udział w jednej z dwóch gier polegających na pojedynczym rzucie monetą. W pierwszej grze jego wypłaty wynoszą: 0 - gdy wypadnie orzeł i 0 - gdy wypadnie reszka. W alternatywnej grze wypłaty są następujące: -100 - gdy wypadnie orzeł i 100 - gdy wypadnie reszka. Zgodnie z kryterium Laplace'a decydent powinien być indyferentny względem obu gier, gdyż wartość oczekiwana ich wypłat jest taka sama. Nie zmienia to jednak faktu, że ostateczny wybór najprawdopodobniej będzie związany z poziomem awersji do ryzyka cechującym danego decydenta.

9 Duplikacja kolumny polega na powiększeniu zbioru możliwych stanów natury o kolejny identyczny z jednym z już istniejących. 


\section{Między pesymizmem a optymizmem}

Z przedstawionego $\mathrm{w}$ poprzednim paragrafie zestawienia wynika, że jedynie kryterium fatalistyczne zaleca wybór opcji „nie robić nic”. Wszystkie pozostałe kryteria jednoznacznie zalecają podjęcie decyzji ostrożnościowej. Jednakże owa jednoznaczność - poza przypadkiem kryterium maximinowego oraz kryterium Savage'a - wynika ze sposobu, w jaki sytuacja decyzyjna została skonstruowana i przedstawiona w macierzy wypłat. W szczególności chodzi o wskazywany wcześniej warunek stosowalności ZO, jakim jest nieakceptowalne społecznie zagrożenie.

Samo określenie danego zagrożenia jako „nieakceptowalnego” wiąże się z tym, że wypłata związana z materializacją takiego stanu rzeczy musi być ujemna i nieskończenie wysoka (nieakceptowalna = żadna inna wypłata nie jest w stanie jej zbilansować). Oznacza to, że decydent stoi w obliczu sytuacji, w której ma bardzo dużo do stracenia. Problem polega na tym, że w takich okolicznościach przypisywanie wartości prawdopodobieństwa poszczególnym stanom rzeczy (a to właśnie pośrednio zaleca część omawianych kryteriów) nie ma znaczenia.

Jeżeli bowiem dana sytuacja decyzyjna zostanie opisana przy użyciu nieskończonych bądź odpowiednio wysokich (kilka rzędów wielkości) wypłat, wówczas stosowanie klasycznych kryteriów decyzyjnych sprowadza się do wyboru między optymizmem a pesymizmem. Wyobraźmy sobie, że decydent ma wybrać jedną z dwóch opcji. Opcja pierwsza oznacza dla niego śmierć (reprezentowaną przez nieskończenie niską wypłatę:- $-\infty$ ) z prawdopodobieństwem $99,9 \%$. Natomiast opcja druga wiąże się z ryzykiem utraty życia z prawdopodobieństwem $0,1 \%$. Intuicja zdecydowanie podpowiada, że należy wybrać opcję drugą. Jednakże wykorzystanie formalnych kryteriów decyzyjnych staje się kłopotliwe, ponieważ zalecane w takiej sytuacji obliczanie wartości oczekiwanej w jednym i drugim przypadku daje wynik nieskończenie niski. A zatem matematyczne kryterium sugeruje, aby decydent pozostał indyferentny względem obu wariantów, a swoją decyzję podjął za pomocą na przykład rzutu monetą. Paradoksalność tej sytuacji wynika ze stosowania wartości nieskończonych.

Wprawdzie w rozważanym przykładzie wartości nieskończone nie pojawiają się, za to scenariusz, w którym okazuje się, że GMO stanowi zagrożenie dla ludzkości - wiąże się z tak wysoką wypłatą, że w praktyce stosowanie kryteriów decyzyjnych daje przewidywalny wynik. Na przykład w przypadku kryterium Hurwicza współczynnik optymizmu powinien wynosić 99,9\% żeby decydent mógł brać pod uwagę wybór drugiej opcji, a kryterium Laplace'a zawsze będzie sugerowało wybór wariantu ostrożnościowego.

Wniosek jest zatem taki, że kryteria decyzyjne konstruowane na podstawie wartości oczekiwanej stają się bezużyteczne, gdy próbuje się je odnieść do zagrożenia katastrofą, którego prawdopodobieństwo jest niemożliwe do oszacowania. Co więcej, nawet dokładne oszacowanie prawdopodobieństwa zdarzenia katastroficznego nie ma wpływu na proces decyzyjny. 
Wprowadzenie do sytuacji decyzyjnej groźby nieakceptowalnej katastrofy powoduje, że w praktyce decydent może zastosować się do kryterium fatalistycznego lub do któregoś z kryteriów pesymistycznych (maximinu lub Savage’a).

Należy jednak podkreślić, że kierowanie się pesymizmem/ostrożnością będącymi immanentnymi właściwościami kryteriów maximinu i Savage’a niesie z sobą potencjalnie ogromne koszty. Co więcej, decydent, który by w swoich macierzach decyzyjnych uwzględniał wręcz nieprawdopodobne zagrożenia (porwanie przez UFO, tsunami na Bałtyku, samospalenie itp.) - musiałby zaprzestać jakichkolwiek aktywności. $Z$ tego właśnie względu praktyczne posługiwanie się kryteriami ostrożnościowymi jest ograniczone.

W konsekwencji otrzymujemy:

Wniosek nr 3 - uwzględnienie nieakceptowalnego zagrożenia sprawia, że dokładne oszacowanie prawdopodobieństwa zdarzenia katastroficznego nie ma wpływu na proces decyzyjny.

Oznacza to, że faktyczny wybór decydenta w warunkach niepewności i groźby katastroficznego zdarzenia - zostaje w praktyce ograniczony do optymistycznego kryterium fatalistycznego $z$ jednej strony i pesymistycznego kryterium maximinowego $0^{10} \mathrm{z}$ drugiej strony.

\section{Podsumowanie — czy zasada ostrożności jest maximinem?}

Na podstawie dotychczasowych rozważań możliwe jest sformułowanie poglądu, że ZO wykazuje pewne podobieństwa do omówionych kryteriów ostrożnościowych. Literatura przedmiotu dostarcza nawet pewnych interpretacji ZO, które bezpośrednio porównują tę zasadę z kryterium maximinu [Hansson, 1997; Gardiner, 2006]. Swiadczy to o tym, że (1) o ZO można orzekać w sposób zbliżony do formalnych kryteriów podejmowania decyzji, oraz że (2) klasyczne reguły decyzyjne mogą stanowić dogodne narzędzie do analizy ZO.

Należy zatem postawić dwa istotne pytania. (1) Co stanowi o wyjątkowości ZO? (2) Czy możliwe jest zredukowanie ZO do zasady maximinu?

Aby odpowiedzieć na pierwsze pytanie, należy uprzednio zastanowić się nad istotą powstałych w ramach teorii decyzji formalnych kryteriów podejmowania decyzji w warunkach niepewności. Otóż punktem wyjścia teorii decyzji jest pewna sytuacja decyzyjna, do której następnie adresowane są rozmaite kryteria. Ważne jest jednak, że nie jest przedmiotem zainteresowania teorii decyzji to, czy opis owej sytuacji decyzyjnej - przełożony na język teorii, a więc na macierz wypłat adekwatnie opisuje realną sytuację decyzyjną. $Z$ kolei w praktyce decydent - oceniając konkretną sytuację - bierze pod uwagę zarówno trafność opisu tej sytuacji, jak i kryteria, na podstawie których dokona wyboru. Tymczasem teoria decyzji

10 Pomijam kryterium Savage'a, które jako kryterium pesymistyczne jest pewnym wariantem reguły maximinu, a w przypadku tak uproszczonych sytuacji decyzyjnych, jakie rozważane są w kontekście ZO - praktycznie można określić te reguły mianem jednakowych. 
interesuje się tylko tą drugą kwestią [Szaniawski, 1971]. Z tego punktu widzenia porównywanie formalnych kryteriów decyzyjnych z ZO wydaje się karkołomne. Wszakże w przypadku ZO analiza tego, czy dane okoliczności wskazują na możliwość jej aplikacji, jest co najmniej tak samo ważna jak sam algorytm decyzyjny.

Wymienione wcześniej kryteria stosowania ZO, czyli: niepewność sensu largo i niepewność nauki sensu stricto oraz nieakceptowalne społecznie zagrożenie to warunki brzegowe, które wymagają pogłębionej analizy i często budzą większe kontrowersje, niż sam przepis na podjęcie decyzji. Przykładem jest chociażby rozważana kwestia GMO. Dyskusje wokół tego tematu nie koncentrują się wcale na tym, jakiego rodzaju kryterium wyboru ma zostać zastosowane, ale raczej na tym, czy wiedza naukowa, jaką dysponujemy na temat GMO, jest wystarczająca, tudzież jak groźne jest ewentualne zagrożenie produktami GMO. A zatem w gruncie rzeczy dyskusja dotyczy tego, jak ma wyglądać macierz wypłat. ZO dostarcza (a przynajmniej ma taką ambicję) ram interpretacyjnych danej sytuacji oraz kryterium decyzyjne. $Z$ tej perspektywy znacząco różni się od kryteriów rozważanych w ramach teorii decyzji.

Wydaje się zatem, że nie jest możliwe utożsamienie $\mathrm{ZO}$ z żadną regułą decyzyjną, gdyż kryteria formalne są koncepcjami o znacznie szerszym znaczeniu. Zasada ta nie odnosi się do wszystkich decyzji, ale jedynie do tych, w których spełnione są warunki jej stosowalności, a to znacząco pomniejsza spektrum sytuacji decyzyjnych branych pod uwagę.

Ponadto - za Randallem [2009] - należy podkreślić jeszcze jedną kwestię. Mianowicie zasadniczą słabością standardowych ujęć stosowanych w zarządzaniu ryzykiem jest to, że są one nieadekwatne w analizie sytuacji związanych z nieakceptowanym zagrożeniem (katastrofą), niskim prawdopodobieństwem oraz wysoką niepewnością. Omówiony przykład GMO pokazał, że również formalne kryteria decyzyjne są wrażliwe na niektóre z tych okoliczności.

Biorąc to wszystko pod uwagę, można udzielić odpowiedzi także i na pytanie drugie - czy możliwe jest zredukowanie ZO do kryterium maximinu. Otóż nie. Nie da się dokonać takiej redukcji. Co najwyżej uprawnione jest stwierdzenie, że o ZO możemy orzekać na przykład jako o konkretyzacji kryterium maximinu. Przede wszystkim jednak należy jeszcze raz podkreślić to, że reguła maximinu jest niepraktyczna. Nie budzi zastrzeżeń stwierdzenie, że ostrożność jest konieczna, ale niezbędne jest narzucenie jej pewnych ram, odróżnienie zagrożenia możliwego od wyobrażeniowego. Takich ram nie dostarcza kryterium maximinowe, ponieważ odnosi się ono wyłącznie do już istniejących macierzy wypłat. ZO próbuje stworzyć takie ramy, dlatego od strony jakościowej jest ideą o zupełnie innej naturze niż jakiekolwiek formalne kryterium teorii decyzji. 


\section{Bibliografia}

Akins A., Lyver P., Alrøe H.F., Moller H. (2019), The Universal Precautionary Principle: Nee Pillars and Pathways for Environmental, Sociocultural, and Economic Resilience, ,Sustainability", 11 (8).

Gardiner S.M. (2006), A Core Precautionary Principle, „The Journal of Political Philosophy", 14 (1).

Hansson S.O. (1997), The Limits Of Precaution, „Foundations of Science”, 2.

Jablonowski M. (2005), High - Risk Decisions When Probabilities Are Unknown (or Irrelevant), ,Risk Management”, 7 (3).

Jablonowski M. (2006), Precautionary Risk Management, Palgrave Macmillan, New York.

Malinowski G.M. (2018), Zasada ostrożności, czyli heurystyka strachu oraz heurystyka odwagi w kontekście polityki gospodarczej, „Prakseologia”, 160 (2018).

Malinowski G.M. (2019), Niepewność nauki a działanie, czyli-problemy z Evidence Based Policy, „Edukacja Ekonomistów i Menedżerów”, 53 (4) (w przygotowaniu).

Moss R.H., Schneider S.H. (2000), Uncertainties in the IPCC TAR. Recommendations to Lead Authors for More Consistent Assessment and Reporting, [w:] R. Pachauri, T. Taniguchi, K. Tanaka (ed.), Guidance Papers on the Cross Cutting Issues of the Third Assessment Report of the IPCC, World Meteorological Organization, Geneva.

Randall A. (2009), We Already Have Risk Management - Do We Really Need the Precautionary Principle?, „International Review of Environmental and Resource Economics”, 3 (1).

Raffensperger, C., Tickner J. (1999), Protecting Public Health and the Environment: Implementing the Precautionary Principle, Island Press, Washington D.C.

Randall A. (2011), Risk and Precaution, Cambridge University Press, Cambridge.

Redziak Z. (2013), Niepewność w podejmowaniu decyzji, „Zeszyty Naukowe AON”, 2 (91).

Resnik D.B. (2004), The Precautionary Principle and Medical Decision Making, ,Journal of Medicine and Philosophy", 29 (3).

Scruton R. (2017), Zielona Filozofia. Jak poważnie myśleć o naszej planecie, tłum. J. Grzegorczyk, R. Wierzchosławski, Zysk i S-ka, Poznań.

Science for Environment Policy (2017) The Precautionary Principle: Decision Making Under Uncertainty, ,Future Brief”, 18 (Produced for the European Commission DG Environment by the Science Communication Unit, UWE, Bristol), http://ec.europa.eu/scienceenvironment-policy [dostęp: 16.09.2019].

Stirling A., Gee D. (2002), Science, Precaution and Practice, „Public Health Reports”, 117 (6).

Straffin P.D. (2004), Teoria Gier, tłum. J. Haman, Wydawnictwo Naukowe „Scholar”, Warszawa.

Szaniawski, K. (1971), Kryteria podejmowania decyzji, [w:] J. Kozielecki (red.), Problemy psychologii matematycznej, PWN, Warszawa.

Sunstein C.R. (2003), Beyond the Precautionary Principle, „University of Pennsylvania Law Review", 151(3).

Sunstein C.R. (2005), Laws of Fear: Beyond the Precautionary Principle, Cambridge University Press, Cambridge. 
Tickner J., Geiser K. (2004), The Precautionary Principle Stimulus for Solutions- and Alternatives-Based Environmental Policy, „Environmental Impact Assessment Review”, 24 (7-8).

US Chamber of Commerce, (2004), Policy brief about the precautionary principle, Washington DC: Environment, Technology \& Regulatory Affairs Division, http://www.uschamber.com.

Wingspread (1998), Wingspread Statement on the Precautionary Principle, „Rachel's Environment and Health Weekly", 586, http:/www.rachel.org/en/node/3850/ [dostęp: 10.11.2019].

Vlek Ch. (2009), A Precautionary-Principled Approach Towards Uncertain Risks: Review and Decision - Theoretic Elaboration, „Erasmus Law Review”, 2 (2). 